\title{
Purification and Properties of a Proteinase from a Marine Luminous Bacterium, Vibrio splendidus Strain FLE-2
}

\author{
Shigeki Fukasawa, Satoshi Aoki, Naoko Gawazawa \\ and Masako Osumi* \\ Department of Biochemistry, Faculty of Science, Josai University, \\ Sakado, Saitama 350-02, Japan \\ *Department of Biology, Japan Women's University, Mejirodai, \\ Bunkyo-ku, Tokyo 112, Japan \\ Received August 18, 1987
}

\begin{abstract}
A proteolytic, marine luminous bacterium was isolated from seawater and identified as Vibrio splendidus biotype I strain FLE-2. A proteinase from this strain, with a specific activity 21 -fold higher than that of the culture supernatant, was purified to homogeneity. The purified enzyme had a molecular weight of 50,000 . The enzyme was most active at $\mathrm{pH} 8.0$ and $55^{\circ} \mathrm{C}$, and stable below $35^{\circ} \mathrm{C}$. The enzyme activity was completely inhibited by EDTA, orthophenanthrolin and phosphoramidon. Also metal ions such as $\mathrm{Cu}^{2+}, \mathrm{Hg}^{2+}, \mathrm{Ni}^{2+}, \mathrm{Cd}^{2+}$ and $\mathrm{Co}^{2+}$ inhibited the activity. These results indicate that this enzyme is a metal-chelater-sensitive, alkaline proteinase.
\end{abstract}

Bioluminescent bacteria are commonly found in the marine environment as free-living forms, saprophytes, parasites, commensal forms and light organ symbionts. ${ }^{1 \sim 3)}$ While much is known about their ecological distribution, their physiology and the control mechanisms of their luminescent systems, ${ }^{1} \sim 3$ ) production of extracellular enzymes has not been investigated except for the use of certain extracellular enzymes for their taxonomic identification. $^{2 \sim 6)}$

Many kinds of microbial proteinases have been reported, ${ }^{7,8)}$ and it is also known that numerous marine bacteria produce proteolytic enzymes, ${ }^{9 \sim 17)}$ but as yet little information is available on the proteinases of marine luminous bacteria.

Here we report the identification of a proteolytic, marine luminous bacterium, FLE-2, which was isolated from among two hundred and fifty-one luminous strains (FLE-1 through FLE-251; free-living, series E) obtained from surface coastal water at Teradomari, Niigata prefecture, Japan, and the purification and some properties of the proteinase from this luminous strain, since the proteinase activity of the culture supernatant of the FLE-2 strain was 3.5-fold higher than those of Vibrio splendidus ATCC 33125 and other $V$. splendidus isolates.

\section{MATERIALS AND METHODS}

Isolation and identification. Seawater was obtained from surface coastal water at Teradomari, Niigata prefecture, Japan, during June, 1984, and spread-plated $(50 \mu 1$ per plate) on MN agar, ${ }^{18,19)}$ which is a nutritionally complete, seawater medium. Isolation of luminous strains was carried out according to the method described previously. ${ }^{20}$ ) Identification was carried out according to the methods of Reichelt and Baumann, ${ }^{4}$ Baumann and Baumann, ${ }^{2}$ Yang et $a .^{5)}$ and Baumann et al. ${ }^{61}$

Preparation of extracellular proteinase test medium. Extracellular proteinase activity was detected on milk seawater agar-seawater agar two layer plates. In preparing this test agar medium, the two layers were poured separately, in a similar manner to in the case of milk agarmarine agar two layer plates. ${ }^{21)}$ The bottom layer consisted of $300 \mathrm{ml}$ of distilled water with $20 \mathrm{~g}$ of skim milk dissolved in it, and $700 \mathrm{ml}$ of seawater containing $50 \mathrm{ml}$ of $1 \mathrm{M}$ Tris- $\mathrm{HCl}$ buffer ( $\mathrm{pH} 7.8$ ) and $15 \mathrm{~g}$ of agar. The two solutions were autoclaved separately $\left(15 \mathrm{~min}\right.$ at $\left.121^{\circ} \mathrm{C}\right)$, cooled to $55^{\circ} \mathrm{C}$ and then mixed aseptically just before pouring. After the milk seawater layer had solidified, the 
MN agar layer was poured on top.

Chemicals. Casein (Hammersten) was purchased from Merck. Sephadex G-100, Sephadex G-100 superfine, DEAE-Sephacel and molecular weight markers for SDSPAGE were obtained from Pharmacia, and molecular weight markers for gel filtration from Boehringer Mannheim. Phosphoramidon, pepstatin A, leupeptin, antipain and chymostatin were obtained from the Protein Research Foundation. PMSF (phenylmethylsulfonylfluoride), PCMB ( $p$-chloromercuribenzoate), IAA (iodoacetic acid) and TPCK ( $p$-toluenesulfonyl- $L$-phenylalanine chloromethyl ketone) were obtained from Nakarai. DTNB (5,5'-dithiobis(2-nitrobenzoic acid)) and other chemicals were obtained from Wako Pure Chemical Industries.

Cultivation. Cells, FLE-2, were inoculated into $500 \mathrm{ml}-$ Sakaguchi flasks containing $120 \mathrm{ml}$ of BGPY (basal glycerol peptone yeast extract) medium $[500 \mathrm{ml}$ of artificial seawater containing $35.1 \mathrm{~g}$ of $\mathrm{NaCl}, 1.5 \mathrm{~g}$ of $\mathrm{KCl}, 24.7 \mathrm{~g}$ of $\mathrm{MgSO}_{4} \cdot 7 \mathrm{H}_{2} \mathrm{O}$ and $2.9 \mathrm{~g}$ of $\mathrm{CaCl}_{2} \cdot 2 \mathrm{H}_{2} \mathrm{O}$ per liter; $444 \mathrm{ml}$ of distilled water; $1 \mathrm{ml}$ of $10 \%$ ammonium ferric citrate solution; $1 \mathrm{ml}$ of $7.5 \% \mathrm{~K}_{2} \mathrm{HPO}_{4}$ solution; $5 \mathrm{ml}$ of $20 \%$ $\mathrm{NH}_{4} \mathrm{Cl}$ solution; $50 \mathrm{ml}$ of $1 \mathrm{M}$ Tris- $\mathrm{HCl}$ buffer $(\mathrm{pH} 7.8) ; 3 \mathrm{~g}$ of glycerol; $5 \mathrm{~g}$ of Bacto-peptone (Difco); and $3 \mathrm{~g}$ of yeast extract (Difco)]. Cultivation was carried out at $23^{\circ} \mathrm{C}$ for $24 \mathrm{hr}$ with shaking as previously described. ${ }^{22}$ After cultivation, the cells were removed from the culture by centrifugation at $12,000 \times g$ and the enzyme was purified from the supernatant.

Assaying of proteinase activity. The proteinase activity was measured according to the method of Hagihara et al. ${ }^{23)}$ The assay mixture contained $0.25 \mathrm{ml}$ of $2 \%$ casein (Hammersten) solution, $0.25 \mathrm{ml}$ of $100 \mathrm{~mm}$ Tris $\mathrm{HCl}$ buffer $(\mathrm{pH} 7.8)$ in $6 \% \mathrm{NaCl}$ and $0.25 \mathrm{ml}$ of enzyme solution. After incubation for $10 \mathrm{~min}$ at $30^{\circ} \mathrm{C}$, the reaction was stopped by the addition of $0.75 \mathrm{ml}$ of $8.5 \%$ trichloroacetic acid. The mixture was stirred vigorously and then centrifuged at $15,000 \times g$ for $5 \mathrm{~min}$. The absorbance of the supernatant was measured at $280 \mathrm{~nm}$ with a Shimadzu UV-120-02 spectrophotometer. Blanks were prepared by adding the enzyme solution after adding the trichloroacetic acid solution. One unit of proteinase activity was defined as the amount of enzyme which liberated $1 \mu \mathrm{g}$ of tyrosine per ml per minute.

Determination of protein concentration. The protein concentration was determined by the method of Lowry et al. ${ }^{24)}$ with bovine serum albumin as a standard.

Purification of the proteinase. Ammonium sulfate was added to the culture supernatant $(600 \mathrm{ml})$ to $100 \%$ saturation. The precipitate was dissolved in an aliquot of $20 \mathrm{~mm}$ Tris- $\mathrm{HCl}$ buffer ( $\mathrm{pH} 7.8$ ) and then dialyzed against $10 \mathrm{~mm}$ Tris- $\mathrm{HCl}$ buffer $(\mathrm{pH} 7.8)$ at $4^{\circ} \mathrm{C}$ for 3 days. The dialyzate $(300 \mathrm{ml})$ was mixed with DEAE-Sephacel which had been previously equilibrated with $20 \mathrm{~mm}$ Tris- $\mathrm{HCl}$ buffer ( $\mathrm{pH} 7.8$ ). The enzyme was eluted with the same buffer containing $0.6 \mathrm{M} \mathrm{NaCl}$. The active fractions were combined and then applied on a Sephadex G-100 column $(3.0 \times 46 \mathrm{~cm})$ equilibrated with the same buffer. The proteinase was eluted as a single peak and then collected. The purified enzyme solution had a specific activity of 1888 . DEAE-Sephacel and Sephadex G-100 chromatography were carried out at room temperature $\left(20 \sim 23^{\circ} \mathrm{C}\right)$.

Electrophoresis. Polyacerylamide disc gel electrophorsis was performed by the method of Davis. ${ }^{25}$ Sodium dodecylsulfate polyacrylamide gel electrophoresis (SDSPAGE) was performed by the method of Weber and Osborn. ${ }^{26)}$ After electrophoresis, the gel was sliced and the slices were chopped up in test tubes with the buffer. The eluates were assayed for proteinase activity.

Estimation of molecular weight. The molecular weight of the purified enzyme was estimated by SDS-PAGE and gel filtration on a column of Sephadex G-100 superfine $(1.5 \times 93 \mathrm{~cm})$ by the method of Determann and Michel. ${ }^{27)}$

\section{RESULTS AND DISCUSSION}

\section{Proteolytic activity and identification}

Extracellular proteinase activity was detected on milk seawater agar-seawater agar two layer plates, as shown in Fig. 1. The characteristics of the proteolytic, marine luminous bacterium, FLE-2, are shown in Table I and Fig. 2. The FLE-2 strain is a moderately luminous, motile gram-negative, curved rod. It has seathed polar flagella, does not accumulate

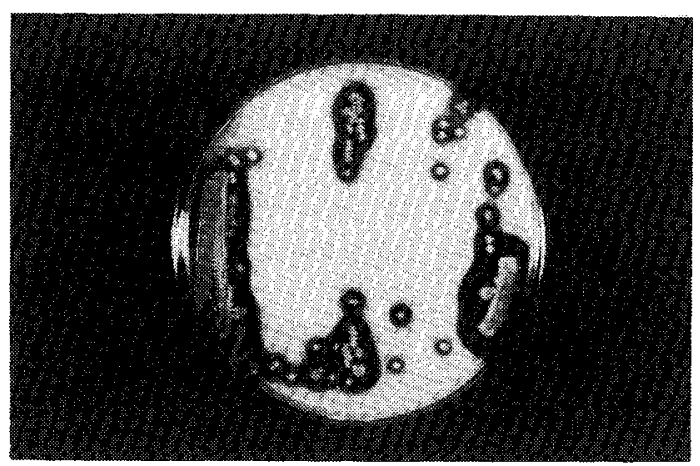

FIG. 1. Behavior of the Proteolytic, Luminous Bacterium, FLE-2, on a Milk Seawater Agar-Seawater Agar Two Layer Plate.

The inoculated agar medium was incubated at $25^{\circ} \mathrm{C}$ for $48 \mathrm{hr}$. Clear zones indicating proteolytic activity can be seen around colonies. 
Table I. Phenotypic Characterization of the Proteolytic, Luminous Bacterium, Fle-2 ${ }^{a}$

\begin{tabular}{|c|c|c|c|c|c|c|c|}
\hline \multirow[b]{2}{*}{ Traits } & \multirow[b]{2}{*}{ FLE-2 } & \multicolumn{6}{|c|}{ Previously reported characterizations ${ }^{b}$} \\
\hline & & $\begin{array}{c}\text { Vibrio } \\
\text { splendidus } \\
\text { biotype I }\end{array}$ & $\begin{array}{l}\text { Vibrio } \\
\text { harveyi }\end{array}$ & $\begin{array}{l}\text { Vibrio } \\
\text { orientalis }\end{array}$ & $\begin{array}{l}\text { Vibrio } \\
\text { fischeri }\end{array}$ & $\begin{array}{c}\text { Photobacterium } \\
\text { phosphoretum }\end{array}$ & $\begin{array}{c}\text { Photobacterium } \\
\text { leiognathi }\end{array}$ \\
\hline Luminescence & + & + & + & + & + & + & + \\
\hline Straight rods $s^{c}$ & - & - & + & - & 98 & + & 97 \\
\hline PHB-Accumulation $^{d}$ & - & - & - & + & - & + & $t$ \\
\hline Gas from D-glucose & - & - & - & - & - & 94 & 39 \\
\hline Arginine dihydrolase & + & + & - & + & - & - & - \\
\hline Growth at $4^{\circ} \mathrm{C}$ & + & 25 & - & + & - & 95 & - \\
\hline $20^{\circ} \mathrm{C}$ & + & + & + & + & + & + & + \\
\hline $30^{\circ} \mathrm{C}$ & + & + & + & + & 92 & 85 & + \\
\hline $35^{\circ} \mathrm{C}$ & - & 75 & + & + & 67 & - & 93 \\
\hline \multicolumn{8}{|c|}{ Growth on single carbon and energy sources: } \\
\hline Maltose & + & + & + & + & 92 & 99 & - \\
\hline Cellobiose & + & + & + & + & 92 & - & - \\
\hline D-Gluconate & + & 25 & 99 & + & - & 86 & + \\
\hline D-Glucuronate & - & + & 99 & - & - & 52 & - \\
\hline DL-Lactate & + & + & + & + & - & 16 & + \\
\hline Mannitol & + & + & + & + & 92 & - & - \\
\hline $\mathrm{D}-\alpha$-Alanine & + & + & 99 & + & - & - & - \\
\hline DL- $\beta$-Hydroxybutyrate & - & - & - & + & - & - & - \\
\hline Acetate & + & 75 & 93 & + & - & - & - \\
\hline Propionate & + & + & 55 & - & - & - & - \\
\hline L-Tyrosine & + & 75 & + & - & - & - & - \\
\hline Pyruvate & + & + & + & + & - & - & 97 \\
\hline$\alpha$-Ketoglutarate & + & + & 91 & - & - & - & 3 \\
\hline L-Proline & + & + & + & + & + & 6 & 97 \\
\hline Sucrose & - & 75 & 61 & + & 8 & - & - \\
\hline Salicin & - & - & 55 & - & 42 & - & - \\
\hline Caprylate & - & - & 67 & - & - & - & - \\
\hline Pelargonate & - & - & 84 & - & - & - & - \\
\hline \multicolumn{8}{|c|}{ Production of extracellular enzymes: } \\
\hline Amylase & + & + & + & + & - & - & - \\
\hline Gelatinase & + & + & 99 & + & 8 & - & - \\
\hline Lipase & + & + & + & + & 92 & - & 80 \\
\hline
\end{tabular}

$a+$, all strains positive; - , all strains negative; numbers indicate $\%$ of positive strains.

$b$ Data abstracted from Reichelt and Baumann, ${ }^{4)}$ Baumann and Baumann, ${ }^{2)}$ Yang $e t$ al. ${ }^{51}$ and Baumann $e f$ al. ${ }^{61}$ and the references cited therein.

+ , straight rods; - , curved rods.

d Ability to accumulate poly- $\beta$-hydroxybutyrate as an intracellular reserve product.

poly- $\beta$-hydroxybutyrate, does not produce gas on fermentation of D-glucose and exhibits arginine dihydrolase activity. This strain grows at 4,20 and $30^{\circ} \mathrm{C}$, but not at $35^{\circ} \mathrm{C}$. It utilizes a variety of compounds as sole carbon and energy sources, but is unable to grow on D-glucuronate, DL- $\beta$-hydroxybutyrate, sucrose, salicin, caprylate or pelargonate. This strain produces amylase, gelatin- ase and lipase. These results indicate that the proteolytic, luminous bacterium, FLE-2, is Vibrio splendidus biotype I.

The production of extracellular proteinases by $V$. splendidus ATCC 33125 and other $V$. splendidus isolates in the FLE series was also observed with the use of this two layer test medium. The proteinase activity of the culture supernatant of the FLE-2 strain was 3.5-fold 
Table II. Summary of Purification of THE Proteinase from Vibrio splendidus FLE-2

\begin{tabular}{lcccc}
\hline Procedures & $\begin{array}{c}\text { Total } \\
\text { protein } \\
(\mathrm{mg})\end{array}$ & $\begin{array}{c}\text { Total } \\
\text { activity } \\
\text { (units) }\end{array}$ & $\begin{array}{c}\text { Specific } \\
\text { activity } \\
\text { (units/mg) }\end{array}$ & $\begin{array}{c}\text { Yield } \\
(\%)\end{array}$ \\
\hline $\begin{array}{l}\text { Culture supernatant } \\
\text { Ammonium sulfate } \\
\text { precipitation }\end{array}$ & 405 & 36,780 & 91 & 726 \\
$\begin{array}{l}\text { DEAE-Sephacel } \\
\text { Sephadex G-100 }\end{array}$ & 25.5 & 18,510 & 1,278 & 50 \\
\hline
\end{tabular}

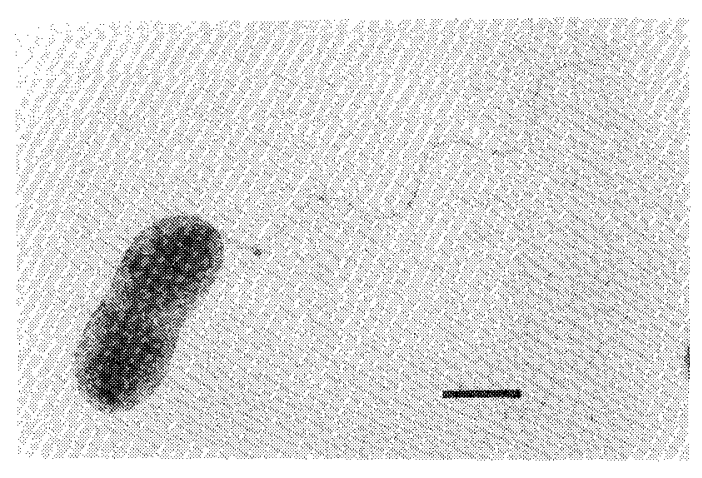

Fig. 2. Electron Micrograph of the Proteolytic, Luminous Bacterium, FLE-2.

Negatively stained. The marker represents $1 \mu \mathrm{m}$ $(\times 8,000)$.

higher than those of $V$. splendidus ATCC 33125 and the other $V$. splendidus strains.

\section{Purification}

The purification of the proteinase from $V$. splendidus FLE-2 is summarized in Table II. The purified proteinase showed 21 -fold purification over the original culture supernatant, with an about $30 \%$ recovery. The purified enzyme showed a single protein band on disc gel electrophoresis, as shown in Fig. 3, and sodium dodecyl sulfate disc gel electrophoresis, which suggests the homogeneity of the preparation.

\section{Molecular weight measurement}

The molecular weights of various bacterial proteinases have been reported, i. e., 34,000 for Bacillus cereus, ${ }^{28)} 46,000$ for Pseudomonas maltophilia, ${ }^{29)} 49,000$ for Vibrio B-30 ${ }^{14)}$ and 60,000 for Serratia sp. ${ }^{30)}$

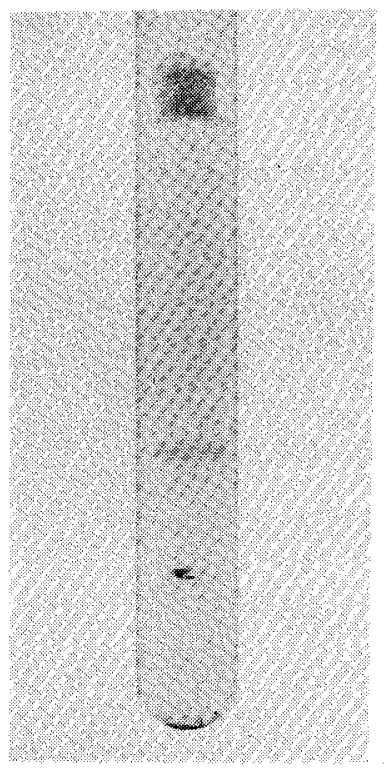

FIG. 3. Polyacrylamide Disc Gel Electrophoresis of the Purified Proteinase.

Electrophoresis was performed using $7.5 \%$ gel as described under Materials And Methods. Protein was stained with Coomassie brilliant blue R-250.

The molecular weight of the proteinase from $V$. splendidus FLE-2 was estimated to be 50,000 by SDS-PAGE, as shown in Fig. 4 , and also estimated to be 50,000 by Sephadex G- 100 superfine gel filtration.

\section{Effects of the $\mathrm{NaCl}$ concentration on activity}

Figure 5 shows the effects of the $\mathrm{NaCl}$ concentration on the enzyme activity. In the experiment, the $\mathrm{NaCl}$ concentration in the assay mixture was varied.

Although the $V$. splendidus FLE-2 strain was isolated from seawater, the proteinase 


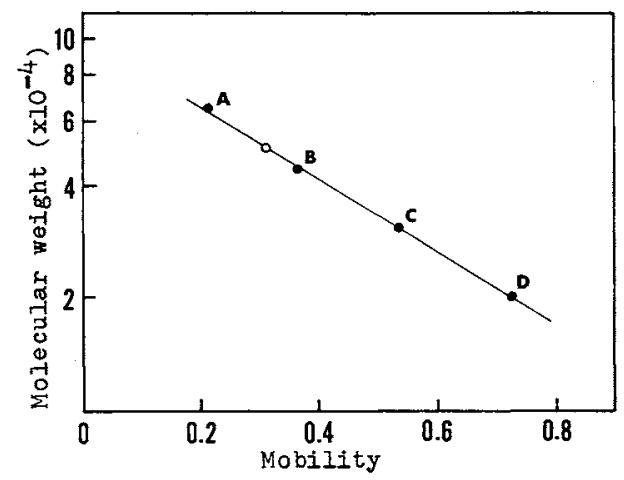

FIG. 4. Estimation of the Molecular Weight of the Purified Proteinase by SDS-Polyacrylamide Gel Electrophoresis.

The standard proteins used and their molecular weights were: A, bovine serum albumin $(67,000)$; $\mathrm{B}$, ovalbumin $(43,000)$; C, carbonic anhydrase $(30,000)$; D, soybean trypsin inhibitor $(20,100)$.

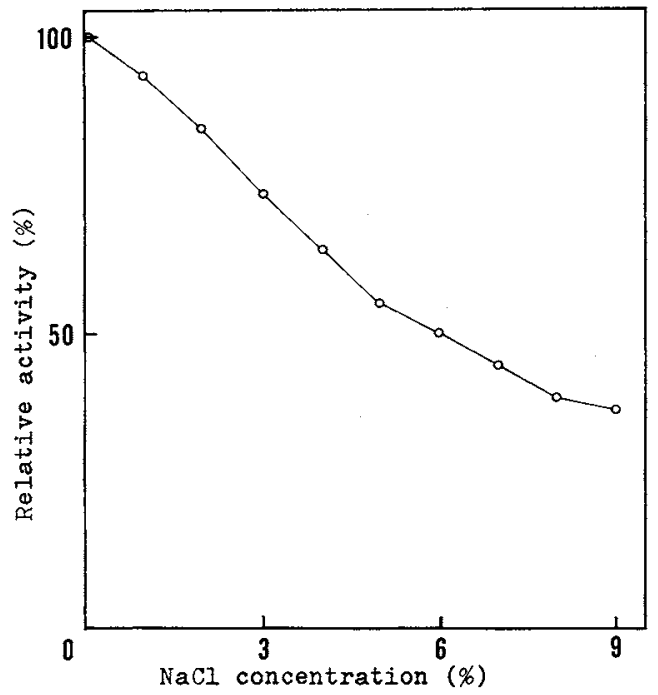

FIG. 5. Effects of the $\mathrm{NaCl}$ Concentration on the Purified Proteinase Activity.

The $\mathrm{NaCl}$ concentration in the assay mixture was varied.

showed higher activity at low $\mathrm{NaCl}$ concentration than that at seawater cencentration $(3 \% \mathrm{NaCl})$, and the enzyme activity was suppressed at high $\mathrm{NaCl}$ concentration, that is, $130 \%$ and $50 \%$ of the original activity (at $3 \%$ $\mathrm{NaCl}$ ) were seen at $0 \%$ and $9 \% \mathrm{NaCl}$, respectively.

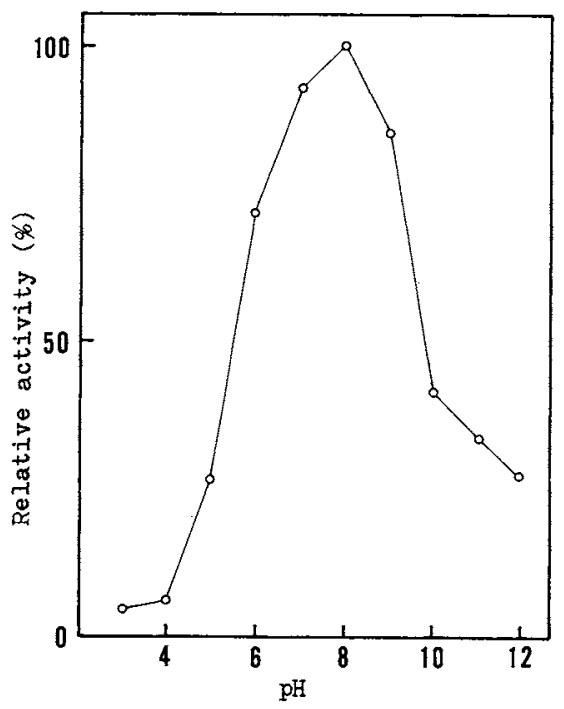

FIG. 6. Effects of $\mathrm{pH}$ on the Purified Proteinase Activity. The buffers used were: $0.1 \mathrm{M}$ Citrate- $\mathrm{Na}_{2} \mathrm{HPO}_{4}(\mathrm{pH} 3 \sim 6)$; 0.1 м K $\mathrm{K}_{2} \mathrm{PO}_{4}-\mathrm{Na}_{2} \mathrm{HPO}_{4}(\mathrm{pH} 6 \sim 8) ; 0.2 \mathrm{M}$ Tris- $\mathrm{HCl}(\mathrm{pH}$ $8 \sim 9) ; 0.1$ м Gly-NaOH (pH 9 12).

\section{Effects of $\mathrm{pH}$ on activity}

The purified enzyme was most active at $\mathrm{pH}$ 8.0 , and showed a somewhat narrow $\mathrm{pH}$ optimum of from 7.0 to 9.0 , as shown in Fig. 6 . This value is similar to those of the alkaline proteinases of Serratia marcescens, ${ }^{9)}$ Pseudomonas sp. ${ }^{16)}$ Serratia sp. ${ }^{30)}$ and Pseudomonas aeruginosa. ${ }^{31)}$

Effects of temperature on stability and activity

The enzyme solution was kept for $30 \mathrm{~min}$ at various temperatures and then the remaining activity was assayed. The proteinase activity was affected by temperature, owing to themolability, above $40^{\circ} \mathrm{C}$, as shown in Fig. 7. The effects of temperature on the activity was also examined (Fig. 7). The maximum activity, which was 1.8 -fold higher than that observed at $30^{\circ} \mathrm{C}$, was seen around $55^{\circ} \mathrm{C}$.

\section{Effects of inhibitors and chemicals}

For this assay system, the reaction mixture without casein as substrate was preincubated with individual effectors in $100 \mathrm{mM}$ Tris- $\mathrm{HCl}$ buffer ( $\mathrm{pH} \mathrm{7.8),} \mathrm{for} 2 \mathrm{hr}$ at $20^{\circ} \mathrm{C}$, and the reaction was started by adding the casein 


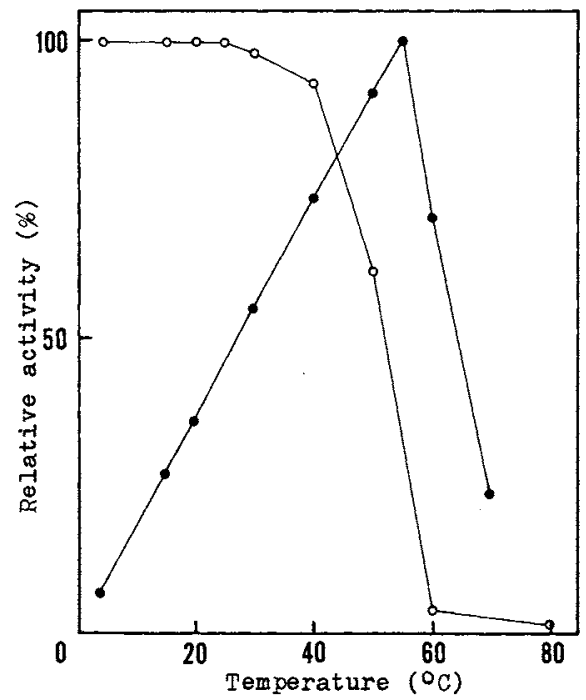

FIG. 7. Effects of Temperature on the Stability and Activity of the Purified Proteinase.

In the experiment on the effects of temperature on the stability $(\mathrm{O}-\mathrm{O})$, the enzyme solution was kept for $30 \mathrm{~min}$ at various temperatures and then the remaining activity was assayed. While, the enzyme reaction was carried out at various temperatures to determine the effects of temperature on the proteinase activity

solution to the assay mixture after preincubation for $10 \mathrm{~min}$ at $30^{\circ} \mathrm{C}$, and then the remaining activities were expressed as percentages of the control activity determined without effectors. The effects of various inhibitors and chemicals on the proteinase activity are shown in Table III. Pepstatin A, leupeptin, antipain and chymostatin did not inhibit the reaction, whereas the purified enzyme was inhibited by metal-chelating agents such as EDTA and orthophenanthrolin, and phosphoramidon. PMSF, PCMB and IAA did not show any inhibitory effect, but dithiothreitol and thioglycol acid affected the reaction. Although some metal ions, such as $\mathrm{Cu}^{2+}$, $\mathrm{Ni}^{2+}, \mathrm{Cd}^{2+}$ and $\mathrm{Co}^{2+}$, strongly inhibited the activity, the $\mathrm{Mg}^{2+}$ and $\mathrm{Ca}^{2+}$ ions did not at all.

These results indicate that this enzyme is a metal-chelater-sensitive, alkaline proteinase.

In the marine environment, luminous bacteria are generally present in the enteric tracts of many fishes and the surrounding water, as
TABlE III. EFFECTS OF VARIOUS INHIBITORS AND Chemicals on the Proteinase Activity

The enzyme was preincubated at $20^{\circ} \mathrm{C}$ for $2 \mathrm{hr}$ with inhibitors and chemicals in $100 \mathrm{~mm}$ Tris- $\mathrm{HCl}$ buffer $(\mathrm{pH}$ 7.8 ), and then the remaining activity was assayed.

\begin{tabular}{|c|c|c|}
\hline Inhibitors and chemicals & $\begin{array}{c}\text { Concentration } \\
\text { (mM) }\end{array}$ & $\begin{array}{c}\text { Remaining } \\
\text { activity } \\
(\%)\end{array}$ \\
\hline Control & - & 100.0 \\
\hline \multirow[t]{2}{*}{ EDTA } & 1.0 & 24.0 \\
\hline & 10.0 & 1.0 \\
\hline \multirow[t]{2}{*}{ Orthophenanthrolin } & 0.1 & 27.0 \\
\hline & 1.0 & 0.0 \\
\hline Phosphoramidon & 0.1 & 8.4 \\
\hline Pepstatin A & 0.1 & 107.0 \\
\hline Leupeptin & 0.1 & 110.0 \\
\hline Antipain & 0.1 & 109.0 \\
\hline Chymostatin & 0.1 & 108.0 \\
\hline PMSF & 1.0 & 106.0 \\
\hline PCMB & 1.0 & 118.0 \\
\hline IAA & 1.0 & 102.0 \\
\hline DTNB & 1.0 & 88.0 \\
\hline TPCK & 1.0 & 95.0 \\
\hline 2-Mercaptoethanol & 1.0 & 88.0 \\
\hline Thioglycol acid & 1.0 & $12: 4$ \\
\hline Dithiothreitol & 1.0 & 55.2 \\
\hline $\mathrm{CuCl}_{2}$ & 1.0 & 3.8 \\
\hline $\mathrm{HgCl}_{2}$ & 1.0 & 58.0 \\
\hline $\mathrm{NiCl}_{2}$ & 1.0 & 17.0 \\
\hline $\mathrm{CdCl}_{2}$ & 1.0 & 39.0 \\
\hline $\mathrm{CoCl}_{2}$ & 1.0 & 37.0 \\
\hline $\mathrm{MgCl}_{2}$ & 1.0 & 104.0 \\
\hline $\mathrm{CaCl}_{2}{ }^{a}$ & 1.0 & 101.6 \\
\hline
\end{tabular}

a Preincubated and assayed in $100 \mathrm{~mm}$ HEPES buffer (pH 7.8).

reported Ruby and Morin. ${ }^{32)}$ The concentration of luminous cells in the nutrient-rich enteric tract may be $10^{5}$ to $10^{6}$ times greater than in the surrounding water, and there is cycling of cells between the enteric contents and the planktonic population. In addition, it has been speculated by Hastings and Nealson $^{33}$ ) that the luminous bacteria may contribute a service to the host by virtue of their production of chitinolytic enzymes. ${ }^{34)}$ This may indicate the dynamics on ecology of the population of luminous bacteria.

As to the optimal activity ( $\mathrm{pH} 7.0 \sim 9.0)$ and stability (below $35^{\circ} \mathrm{C}$ ), the proteinase from the marine luminous bacterium, $V$. splendidus 
FLE-2, is able to function in the marine environment. It may be considered that the proteinase also contributes to the population dynamics as described for chitinolytic enzymes.

Acknowledgments. The authors are grateful to Dr. Yata Haneda for his advice and encouragement. The authors also wish to thank Mses. Misuzu Baba, Sakae Miyakawa and Ikuyo Aoki for their kind support.

\section{REFERENCES}

1) K. H. Nealson and J. W. Hastings, Microbiol. Res., 43, 496 (1979).

2) P. Baumann and L. Baumann, "The Prokaryotes," ed. by M. P. Starr, H. Stolp, H. G. Trüper, A. Balows and H. G. Schlegel, Springer-Verlag, Berlin, Heidelberg and New York, 1981, p. 1301, Chapter 104.

3) J. W. Hastings and K. H. Nealson, "The Prokaryotes," ed. by M. P. Starr, H. Stolp, H. G. Trüper, A. Balows and H. G. Schlegel, SpringerVerlag, Berlin, Heidelberg and New York, 1981, p. 1332, Chapter 105.

4) J. L. Reichelt and P. Baumann, Arch. Mikrobiol., 94, 283 (1973).

5) Y. Yang, L. Yeh, Y. Cao, L. Baumann, P. Baumann, J. S. Tang and B. Beaman, Cur. Microbiol., 8, 95 (1983).

6) P. Baumann, R. H. W. Schubert, A. L. Furniss, J. V. Lee and L. Baumann, "Bergey's Manual of Systematic Bacteriology," Vol. 1, ed. by N. R. Kreig and J. G. Holt, Williams and Wilkins, Baltimore and London, 1984, p. 516.

7) K. Morihara, "Advances in Enzymology," ed. by A. Meister, An Interscience Publication, John Wiley and Sons, New York, London, Sydney and Toronto, 1974, p. 179.

8) H. Matsubara and J. Feder, "The Enżymes," ed. by P. D. Boyer, Academic Press, New York and London, 1971, p. 721.

9) I. J. McDonald and A. K. Chambers, Can. J. Microbiol., 9, 871 (1963).

10) J. R. Merkel, E. D. Traganza, B. B. Mukherjee, T. B. Griffin and J. M. Prescot, J. Bacteriol., 87, 1227
(1964).

11) J. M. Prescot and S. H. Wilkes, Arch. Biochem. Biophys., 117, 328 (1966).

12) Y. Nunokawa and I. J. McDonald, Can. J. Microbiol., 14, 215 (1968).

13) Y. Nunokawa and I. J. McDonald, Can. J. Microbiol., 14, 225 (1968).

14) J. R. Merkel and T. Sipos, Arch. Biochem. Biophys., 145, 121 (1971).

15) T. Sipos and J. R. Merkel, Arch. Biochem. Biophys., 145, 137 (1971).

16) N. Kato, T. Nagasawa, Y. Tani and K. Ogata, Agric. Biol. Chem., 36, 1177 (1972).

17) N. Kato, T. Nagasawa, S. Adachi, Y. Tani and K. Ogata, Agric. Biol. Chem., 36, 1185 (1972).

18) K. H. Nealson, "Methods in Enzymology," Vol. 57, ed. by M. A. DeLuca, Academic Press, New York, 1978, p. 153.

19) S. Fukasawa and P. V. Dunlap, Agric. Biol. Chem., 50, 1645 (1986).

20) S. Fukasawa, P. V. Dunlap, M. Baba and M. Osumi, Agric. Biol. Chem., 51, 265 (1987).

21) R. K. Sizemore and L. H. Stevenson, Appl. Microbiol, 20, 991 (1970).

22) S. Fukasawa, P. Dunlap, Y. Benno and T. Mitsuoka, Microbiol. Immunol., 28, 117 (1984).

23) B. Hagihara, T. Yonetani, T. Yamamoto and $T$. Komaki, "Koso Kenkyuho," Vol. 2, ed. by S. Akabori, Asakura Shoten, 1956, p. 242.

24) O. H. Lowry, N. J. Rosebrough, A. L. Farr and R. J. Randall, J. Biol. Chem., 193, 265 (1951).

25) B. J. Davis, Ann. N.Y. Acad. Sci., 121, 404 (1964).

26) K. Weber and M. Osborn, J. Biol. Chem., 244, 4406 (1969).

27) H. Determann and W. Michel, J. Chromatogr., 25, 303 (1966).

28) B. Holmquist, Biochemistry, 16, 4591 (1977).

29) T. Kobayashi, A. Ogasawara, S. Ito and M. Saitoh, Agric. Biol. Chem., 49, 693 (1985).

30) K. Miyata, K. Maejima, K. Tomoda and M. Isono, Agric. Biol. Chem., 34, 310 (1970).

31) K. Morihara, Biochim. Biophys. Acta, 73, 113 (1963).

32) E. G. Ruby and J. G. Morin, Appl. Envir. Microbiol., 38, 406 (1979).

33) J. W. Hastings and K. H. Nealson, Annu. Rev. Microbiol., 31, 549 (1977).

34) R. Spencer, Nature, 190, 938 (1961). 